\title{
TEXTOS INTEGRADOS Y NARRATOLOGÍAS MÍTICAS Y POSMODERNAS: ALGUNOS PARALELISMOS
}

\author{
Eloy Martos Núñez \\ Universidad de Extremadura, España \\ emarnun@gmail.com \\ Alberto E. Martos García \\ Universidad de Extremadura, España \\ aemargar@gmail.com
}

\section{RESUMEN / ABSTRACT}

Este artículo aborda el análisis de los textos integrados de los cuentos cíclicos y también los instrumentos y herramientas para catalogar los componentes de la ficción en sentido amplio, la forma de definir las unidades de análisis (narratologías) y las poéticas de cada momento histórico, poniendo el énfasis en cómo la recepción de los públicos condiciona las formas concretas de agrupar los textos narrativos. A tal efecto, se revisan los modelos narratológicos del folktale y su aparato descriptivo, y también otros universos narrativos mayores, como la narración serial que subyace a las sagas o a las series televisivas. Otros factores, como la praxis de los nuevos lectores y la propia industria del entretenimiento -franquicias de superhéroes o plataformas como Tropes- revelan el éxito de un discurso posmoderno, no interesado ya en catalogar o elucidar los elementos de las ficciones de su época, sino solamente en "coleccionarlos", a fin de provocar la participación o hacer que converjan diversos medios expresivos. Esta porosidad de categorías y de criterios de agrupamiento es el nexo entre los textos de diferentes culturas literarias -desde la oralidad a la relectura literaria y posmoderna de las mitografías antiguas- y es lo que nos ha permitido trazar algunos paralelismos entre las narrativas míticas y las de la posmodernidad.

Palabras Clave: textos integrados, cuentos cíclicos, narratología, tipos, motivos.

This article deals with the integrated texts of cyclic tales and also the instruments and tools to catalog the components of fiction in a broad sense, the way to define the units of analysis (narratologies) and the poetics of each period, with the emphasis on readers' responses to determine the modes of narrative texts. Narratological models of the folktale and its descriptive 
apparatus have been reviewed, along with other major narrative universes, such as serial narratives underlying sagas and television series. Other current factors, such as the practice of new readers and the entertainment industry, reveal the success of a postmodern discourse which is no longer focused on elucidating the elements of fiction of its own time, but interested in "collecting" them to cause the convergence of various expressive means. This porosity of categories and grouping criteria serves as a link between texts from different literary cultures -from orality to postmodern literary reinterpretation of ancient mythographies-, and allows us to draw parallels between mythic narratives and the narratives of postmodernism.

KEY WORDS: integrated texts, cyclical stories, narratology, types, motif.

\section{INTRODUCCIÓN: LA PROBLEMÁTICA DE LOS TEXTOS INTEGRADOS O LA LABILIDAD DE LAS CATEGORÍAS}

Los llamados "textos integrados" (P. Brescia y E. Romano 2006) son una buena piedra de toque para radiografiar la producción textual de una época o de una literatura dada, por ejemplo, a través de las antologías poéticas de la literatura española del siglo XX se ha construido en gran medida la historiografía literaria de cada periodo. Por ello mismo han servido de forma muy particular para conformar un intertexto literario (A. Mendoza 2002), base del canon: así, bajo el nombre de Floresta u otras rúbricas similares se reunían las "joyas" de una literatura, los textos seleccionados que, a la postre, se convertían en los exponentes más destacados de un corpus literario, y esto no solamente concernía a las antologías o compilaciones de carácter académico o literario, sino a todos los órdenes de la actividad cultural y educativa. De este modo, en los manuales escolares, en las citas "de autoridad", lo que se conformaba con este procedimiento era un determinado universo literario acotado en gran medida con parámetros académicos, y no con criterios de los gustos de los lectores, ahondándose así un cierto divorcio entre el canon oficial de lecturas y lo que el público, en el más amplio sentido de la palabra, demandaba.

A esto se añadía la situacion "excéntrica", si utilizamos las categorías de la teoría de los polisistemas, de corpus enteros como la literatura infantil y juvenil, cuya "invisibilidad" ha sido denunciada reiteradamente por autores y expertos, situación sin duda extensible a otros "archipiélagos" de la literatura, como la llamada literatura de masas. Por tanto, cualquier antología literaria tiene que plantearse, de entrada, esta diversidad de culturas literarias coexistentes, incluyendo aquellas otras modalidades más soterradas (la literatura oral u "oratura", hipotexto actuante en tantas obras consagradas, desde el Quijote 
hasta el Ulises de Joyce), de tal forma que todas estas expresiones vienen a superponerse a la cultura letrada en el sentido de Chartier (1994), la cual coexiste así con los productos de la cultura popular mediática (Saint Gellais 2000) en una nueva síntesis aún por construir.

En efecto, en tiempos de la sociedad de la información y de la posmodernidad, la relativización del canon y de todos los valores culturales y sociales en general ("la modernidad líquida" de Bauman 2005) y en medio de un contexto de creciente mercantilización de la cultura, el criterio de agrupamiento de textos a partir de una jerarquía de autores o géneros ya no es tan evidente ni suscita un consenso generalizado. De hecho, el éxito de los best-sellers o de las sagas se debe en gran parte a mecanismos de marketing, que aorillan un poco los criterios intrínsecamente literarios, y no puede pues plantearse que las antologías tradicionales, basadas en expurgos críticos, sean precisamente tenidas en cuenta por el mercado.

En la actualidad el marketing viral ejerce una importante influencia, se lee aquello que gusta a una mayoría de lectores, y éstos además conforman una "masa participativa" que establece un cierto feed-back con el emisor del texto, que ya no es exactamente un autor, puede ser una "marca" conforme a las franquicias modernas, donde importa menos el sello de un autor físico, al modo tradicional, que el reconocimiento de una marca universalmente extendida. El Señor de los Anillos o Juego de Tronos serían buenos ejemplos de esta nueva dinámica, que rebasa desde luego la relación casi paternal entre autor y público. Es algo que, por cierto, ya se vislumbró en la relación que éste llegó a establecer con el universo de ficción de Sherlock Holmes, que obligó incluso a Conan Doyle a hacer revivir su personaje después de que lo había "hecho morir". El público y el mercado ejercen sus derechos, de tal modo que lo que se conoce como Fan fiction (Martos García 2010) sería el "iceberg" de esta macrotendencia participativa.

En este contexto de reivindicación del lector, P. Brescia y E. Romano (2006) plantean las estrategias para leer textos integrados a la luz de las nuevas teorías y prácticas de la posmodernidad, proponiendo nuevas categorías como el concepto de "ciclo" (Ingram 1971), esto es, historias con un nexo que se puede rastrear a través de textos diferentes, siendo en última instancia el lector quien mejor suele descubrir los patrones de conexión. De hecho, como bien matiza G. Mora (1990), no se puede pensar que el criterio para definir un "cuento cíclico" sea solo la intención autorial o del editor, sino que es el lector quien es capaz de reconocerlo en base a recurrencias como las referidas a que los diversos cuentos compartan un mismo "paracosmos", 
tal como luego se va a evidenciar en las sagas modernas (Martos 2010), que por su naturaleza de narración serial o continua precisan del requisito que S. Garland Mann (1989) atribuye a los cuentos cíclicos, a saber, que estén interrelacionados.

Todo ello se conecta con la teoría de la recepción de Iser (1976), pues cada épica y cada público puede releer los textos conforme a sus propias expectativas y horizontes interpretativos, y el resultado es siempre lo que Gadamer (1977) llama una fusión de horizontes. Eso lo hemos visto en la relectura romántica de los monstruos y espantos ancestrales: sin las leyendas alemanas de espectros es probable que Mary Shelley nunca hubiera escrito Frankenstein, pero sin la estética romántica y su gusto por la soledad, las ruinas y la inclinación por lo oscuro y lo rebelde, es también probable que este personaje no habría tomado forma y que, por tanto, no habría servido de modelo inspirador de toda la subcultura gótica. Ciertamente, su sentido de lo siniestro procede ante todo de fuentes literarias, por más que los trajes, la música o la cosmética pretendan presentarlo como un movimiento ex novo. Apoyando este argumento, vemos que la imaginería de lo macabro -que tanto va a marcar la moderna literatura de vampiros- está ya en el cadalso de Las Noches Lúgubres, cuya fuente última parece ser el tema de la Difunta Pleiteada. Obra que, a su vez, se entronca con lo que ya contaban las baladas europeas (v. gr., El Romance de Conde Olinos), nucleadas sobre el leitmotiv del amor más allá de la muerte. Por consiguiente, este mismo encadenamiento de motivos y tradiciones avala que podamos poner entre paréntesis ciertas etiquetas literarias o algunas atribuciones, al constatar que determinados fenómenos están precisamente "a caballo" entre culturas aparentemente distantes en el tiempo y en sus cosmovisiones. Sin duda, la forma en que un chamán visiona a los espíritus dista bastante de la maquinaria teatral con que se presenta un fantasma en la comedia barroca o en el drama romántico, pero los préstamos son más que evidentes.

Por otra parte, el concepto de "ciclo" ha sido también usado en otro sentido más técnico, como equivalente a "saga", esto es, a una narración continua o serial, que se expande a través de un universo de ficción amplio, el cual contiene su propia cronología, geografía, razas o mito fundacional, tal como aparece en obras tan exitosas como El Señor de los Anillos o Canción de Hielo y Fuego. En realidad, las sagas fantásticas modernas son ejemplos de neoépica expandida, es decir, son fantasías épicas que han construido su propio imaginario, dotado de los atributos antes mencionados y con un horizonte amplio, propio del mito antiguo. Tienen un amplio alcance, capaz 
de crear genealogías y "panteones" de protagonistas, con sus secuelas y precuelas, siguiendo el procedimiento posmoderno de reciclar e hibridar materiales ya preexistentes. Es por ello que muchas de las producciones llamadas de literatura de masas -desde las sagas aludidas a los géneros de terror, vampiros, ciencia ficción o space opera - tienen ese aire compartido de "remix", de conjunción interior de tradiciones heteróclitas que llegan a conformar un nuevo "tronco de ficción".

En todo caso, esta labilidad de categorías y de (sub)géneros ha hecho "saltar por los aires" lo que en la cultura clásica constituían conceptos "estables": autor, texto, género... En consecuencia, tal recategorización pone en cuestión los límites prefijados entre cuento y novela. La única realidad sería la del texto que, precisamente por ser fluctuante y porosa, permite distintos "cortes" y agrupaciones. E. Martos (2010) ha defendido la metáfora del texto como fluido, y con ello la necesidad de diferenciar aquél de sus contenedores o soportes ocasionales. De esta forma, si la antología clásica tendía más a la forma de una serie miscelánea, las antologías modernas estarían más cerca de colecciones integradas cíclicas, donde el cruce de géneros es lo habitual.

\section{LAS NARRATIVAS MÍTICAS: FRAGMENTACIÓN TEXTUAL Y FUNCIÓN SAGRADA}

Stith Thompson (1972), al describir el folktale o narración tradicional, no tuvo más remedio que incluir en él subformas tan distintas -cuando no contrapuestas- como el mito, el cuento maravilloso, la leyenda, la chanza, los cuentos de fórmula, etc., modalidades distintas que es sumamente difícil agrupar con una rúbrica común, si antes no matizamos el tipo de géneros tradicionales implicados, su extensión o su propia variabilidad textual, pues habremos de ponderar si es una determinada variante o hasta qué punto es un etnotexto o bien una versión literaturizada.

Por citar un caso ilustrativo, si mencionamos historias acerca de sirenas o damas de agua -tan comunes en el folclore latinoamericano y europeo-se constata, no solo la labilidad de los subgéneros (¿es la historia de Parténope un cuento, un mito, una leyenda?), sino cómo lo folclórico, lo parafolclórico y lo literario se pueden enhebrar mutuamente, tal como apreciamos en las versiones de los hermanos Grimm sobre Frau Holle y otras ondinas. Hasta el punto de que para un posible agrupamiento textual, en un caso así, apenas bastaría con titular Antología de Sirenas, pero antes harían falta varias operaciones 
previas. A saber, primero habría que reexaminar el criterio más aparente de agrupamiento, nos referimos en este caso a la terminología. Una sirena no es más que una rúbrica falaz, incluso en inglés hay dos denominaciones distintas: syren y mermaid. Y es que los seres de agua arrojan una gran disparidad de nombres (ninfas, sirenas, xanas, nereidas, lamias, Nixe, ondinas, etc.), a veces con connotaciones locales y otras veces funcionando como términos genéricos. Pero, en todo caso, su especificidad es engañosa desde el momento en que, gracias a la transcodificación o transpersonificación, muchos de estos seres no son más que avatares de lo que hemos rotulado de forma genérica como seres de agua; sucede, por ejemplo, que una deidad grecolatina sea traducida en sus atributos y narraciones a otro numen local más o menos equiparable, pero perteneciente a una mitología o religión distinta. Es el fenómeno del sincretismo que aparece de forma tan acusada en casos como la Hispania romana. A este respecto, ni el nombre, ni tan siquiera el aspecto pueden ser guías seguros: necesitamos un enfoque comparativo y una consideración más amplia del entorno para juzgar si esa tradición es genuina, y no un simple calco o imposición "del conquistador". O incluso valorar si estamos ante una divinidad tópica con el nombre alterado, que es lo que sucede a propósito de numerosas ninfas de cultos termales del noroeste de la Península Ibérica. De ahí que, sin fiarnos del todo del nombre o de su iconología, haya otros indicios que atender: los etnotextos conservados, las esferas de acción (Propp 1928) de estas deidades, los motivos asociados, etc. Y esto vale para la prosopografía de los mitos ancestrales y para sus "réplicas modernas", sobre todo cuando las narrativas míticas se transforman en "narrativas de marca" (universo Marvel).

Tampoco cuando tenemos un nombre propio, como Frau Holle, podemos estar seguros del todo de referirnos a una personificación unitaria: en los diversas versiones de este mito de los hermanos Grimm, Frau Holle, en tanto que Märchen (Tipo 480), aparece en forma de numen celeste y del ultramundo que pone a prueba a la "niña buena" y a la "niña mala" (Warren 1958); lo cierto es que en las otras versiones leyendísticas de Frau Holle, por ejemplo como señora de una laguna, los tintes son más sombríos y siniestros, ya no hay ambivalencia ni tareas pactadas con las niñas, sino que se comporta como la Nixe de otros cuentos de Grimm que trae la desgracia a cualquier intruso.

Bajtin (1974) llamaba a esta variedad de versiones "polifonía textual", y a tenor del criterio de Ingram (1971) tales conexiones no son en realidad descubiertas por el compilador, sino más bien en la recepción de los textos, gracias a la "mirada del lector. Así, las ondinas se pueden conectar a ciertos 
tópicos, como estar peinándose en la orilla con un peine de oro, según se puede cotejar en muchas leyendas de encantadas. Pero otras lecturas menos convencionales pueden acaso tomar en consideración otros elementos, como que las ondinas están justo al lado de pozos, fuentes, riberas, cuevas... lo cual no es una casualidad, si entendemos que todos estos son lugares de poder y "umbrales" (Campbell 1949) de acceso al ultramundo.

Lo cierto es que una lectura superficial de Frau Holle apenas percibe el valor simbólico del pozo o de la sangre vertida sobre el agua: que la niña se pinche y se tire al pozo resulta, pues, una concatenación de incidentes que hoy parecen sin duda extravagantes. Pero una lectura que tenga en cuenta los códigos de la cultura del agua, de las ofrendas rituales a estos lugares sagrados que son los pozos, o de la vinculación del hilado con la mujer y las prácticas mágicas, podrá entender esta secuencia textual de una manera más lógica, de tal manera que la progresión temática cobrará sentido, ya que la secuencia subsiguiente es la de las pruebas. En pocas palabras, la ofrenda, la sangre o el tesoro son parte de un contrato no escrito con el genius loci o dios local. Ni siquiera es preciso una lectura esotérica, sino solamente atender a los detalles que el mismo texto proporciona, por disparatados que parezcan a un lector moderno.

En consecuencia, el texto narrativo -que en este caso es el cuento de los Grimm Frau Holle - no tendría una estructura canónica tan estable como la que nos describe el Tipo 480 de Aarne-Thompson (1971), sino más bien una serie de "bloques o secuencias" narrativas que se relacionarían con bastante elasticidad, y que vendrían a ser pequeños scripts o rutinas, las cuales no seguirían exactamente las pautas que Bremond (1974) y otros narratólogos prescriben. En efecto, en el cuento de los hermanos Grimm La ondina y el estanque, el nexo entre el bloque primero y el segundo es la promesa irresponsable, y en La ondina se nos dice que los dos hermanos, jugando, caen al manantial. Por tanto, constatamos que la motivación de la "ofrenda" está muy circunstanciada, se motiva de formas muy diferentes, pero en los tres casos lo que sigue es el desempeño de la prueba.

Es un tópico narratológico, desde los estudios estructurales, afirmar que la idea inicial de un relato se configura como una situación de partida, que es perturbada o modificada por un conflicto (i. e., un secuestro). De ello resulta un estado de desequilibrio que genera un proceso: se emprende la búsqueda de esa persona o cosa que falta, los personajes reaccionan ante ese factor de perturbación, y así sucesivamente. En otras palabras, sobre este suceso base lo que hace el relato es desarrollar distintas posibilidades de complicación, 
lo cual lleva a una reacción ante el suceso, y eso, a su vez, a una resolución. Pero cuentos como Frau Holle desmienten, al menos en parte, tal esquema, porque la complicación o la complejidad no surgen siempre como reacción a un hecho que venga "de fuera", sino que, a menudo, está desde el principio como parte de un código de relación con el genius loci. Por ello, la historia del huso caído al pozo y de la madrastra que ordena a la niña ir a buscarlo, es el consecuente y no el antecedente (éste, en realidad, es el sacrificio que el oferente debe entregar a cambio del don que espera le sea otorgado).

Así que un análisis superficial encuadraría esta escena inicial como parte de una ambientación llena de "motivos libres" (Segre 1985), cuando es precisamente lo esencial del cuento. La complicación desencadenante no es, pues, en este caso una fechoría a manos de la ogresa Frau Holle sino, más bien, lo que tiene que hacer la parte contratante, por así decir, aunque aparezca desvirtuada en forma de mandato de la madrastra (o sea, cambiada de valor, nótese el concepto de iconotropismo de Graves 1948). Precisamente porque lo más obvio se ha hecho lo más opaco, en línea con lo que dice la ecocrítica: lo relevante en la leyenda de San Jorge es el manantial que el dragón guarda, y, sin embargo, es lo que queda soterrado o "invisibilizado", igual que lo principal es que la heroína vaya a hacer una ofrenda al genio del agua que reside en ese pozo (genius loci), el cual es asimilado a Frau Holle, y es de quien se espera recibir un don.

La referida alineación de elementos míticos se hace más evidente si sustituimos la sangre del cuento por las ofrendas -en forma de monedas, clavos u otras prendas- y las pruebas por los conjuros, oráculos o bien por las maldiciones. A este respecto se han encontrado en toda Europa millares de tablillas de maldiciones (defixiones en latín), precisamente en estos lugares de poder, como formas de impetrar a estos dioses ctónicos determinados dones o favores. La resolución desencadenante, por tanto, es el desempeño de las pruebas que sellan el pacto, pues sabemos que el oferente puede "componer" el sacrificio de muy diferentes modos: puede ser él mismo o una parte de él (pensemos en cuentos populares tan extravagantes hoy como La niña sin brazos), o bien con otros presentes, como los panes que la niña ha de saber hornear. Todo lo demás, el don otorgado, el gallo e, incluso, el episodio geminado de la "niña mala", apenas es más que un adorno de la historia base.

A tenor de todo esto, ¿por qué habríamos de relacionar este cuento solo con historias de ondinas o de pozos y no con otros relatos como Las princesas bailadoras, La casa del bosque, La lámpara azul, etc.? En otras palabras: hay que prestar atención a otro elemento esencial de la tradición, la relectura 
ritual y socializada (midrash) de los textos, tomados en su transmisión en cadena; es decir, un texto no tiene un sentido único ni es acotado hasta que la comunidad en que pervive lo glosa, lo comenta, lo incorpora a sus ritos y costumbres, como las tradiciones judías de la Pascua (Gunkel 1910). Por eso, dice Pollastri (2006) que en estos casos la creación es una acción diferida de sentido, equidistante entre el marco originario, sea cual sea éste, y la actualidad desde la que se reinterpreta. Eso mismo ocurre en las fiestas y en otros elementos del patrimonio inmaterial: siempre hay un cruce de tiempos, de códigos. El valor ancestral subyacente o el hipotexto ritual de las procesiones de Corpus Cristi, con sus máscaras, fieras y otros detalles, se conjugan con los valores que se han ido añadiendo en épocas históricas o modernas, y todo ello se funde en una amalgama que cobra un sentido derivado de este sincretismo.

Al margen de toda esta complejidad, la escuela finlandesa actuó pragmáticamente creando unos determinados instrumentos, para segmentar el material narrativo disponible en innumerables colecciones y recopilaciones de todo el mundo. Sus opciones, según veremos, han fosilizado los textos tradicionales en pos de una cierta utopía: descubrir los "ladrillos" de la narración $\mathrm{y}$, a partir de ahí, establecer ciertos repertorios y prototipos con el resultado de crear no solo un sistema de clasificación, sin duda loable, sino también una percepción sesgada de todo el material fabulado, estableciendo títulos, descripciones, subclasificaciones y apartados, que no siempre se sostienen. Cierto que el fin pretendido no era el que nos ocupa -una hermenéutica de la narración tradicional- sino más bien un procedimiento de catalogar todo el ingente material acumulado. Sea como sea, es lógico que no queramos desvincular ambas tareas, pues está en juego no solamente la manera de clasificar sino también de agrupar estos textos, y los epígrafes de AarneThompson son, como venimos argumentando, un procedimiento discutible e incluso perjudicial, si lo que pretendiéramos fuera -según los aires de la posmodernidad- una deconstrucción de la leyenda que supusiera una relectura de la serpiente, los ogros o los supuestos adversarios, o bien una relectura no menos incisiva de los supuestos ayudantes, tal como acabamos de ver en el caso de Frau Holle.

Así, Fernando Savater (1997) ha hecho una agrupación sugerente de los antihéroes populares en Malos y malditos, que, sin duda, podría hacerse con mayor fundamento en el terreno del mito, y que es lo que hace la ecocrítica, por ejemplo, al reivindicar a la Hidra frente a Hércules, o la perspectiva de género, al denunciar la demonización de la mujer en mitos como Medea. 
Abordar estos pasajes con esta otra mirada supone también poner en valor la lectura crítica y desarmar estereotipos largo tiempo vigentes.

\section{LAS PRECONCEPCIONES DE LAS TAXONOMÍAS DE LA ESCUELA FINLANDESA}

Desde hace décadas se cita profusamente el aparato taxonómico de AarneThompson (1961), en relación con las narraciones tradicionales, como referente científico de primera magnitud, y ciertamente lo es, si bien falta una revisión a fondo de las preconcepciones de su clasificación y de las posibles alternativas. Lejos de ser un debate puramente teórico, el establecimiento de unos u otros ejes clasificatorios conlleva unas importantes repercusiones en cuanto a la recepción de este inmenso corpus folclórico, y, por ende, en la forma de agrupar los textos dentro de unas u otras subclasificaciones. Sin duda, todos los paradigmas, desde la escuela histórico-geográfica al análisis estructural, han aportado elementos interesantes, si bien las corrientes surgidas al amparo de un clima cultural posmoderno han supuesto un giro en el método de análisis y en la aproximación hermenéutica, de ahí que sus conclusiones sean tan contrarias a las establecidas por los métodos de la escuela finlandesa o, incluso, por los del estructuralismo.

En efecto, la escuela finlandesa trazó un sistema clasificatorio para organizar las distintas colecciones de folktales de todo el mundo, identificando los tipos de cuentos y aislando los motivos. El catálogo inicial fue desarrollado y publicado en 1910, en alemán, por Aarne bajo el título Índice de los tipos de historia en el folclore, y luego ha sido reeditado sucesivamente como la Taxonomía de Antti Aarne y Stith Thompson. El problema fundamental de este sistema, a pesar de su dilatada trayectoria, es la creación de los bloques de clasificación a partir de (sub)categorías muy discutibles, tanto desde el punto de vista formal como de contenidos. En cuanto a la segmentación en tipos y motivos es sin duda útil, el problema estaría en que se echa en falta una escala intermedia. Hemos visto en Frau Holle que, entre el motivo aislado del pozo y el Tipo 480, perfectamente delimitado en el catálogo, faltaría establecer el script que define precisamente la primera secuencia, y que es una especie de molécula narrativa: la asociación pozo-ofrendaoferente, dado que es precisamente esta iniciativa, y no ninguna otra acción, el arranque del cuento. 
Otra inconsistencia, a nuestro juicio, es en relación con los actantes: nos referimos a la separación entre Adversarios/Aliados que justifica la división entre los tipos de los cuentos de magia. Así, del 300 al 399 se postulan dentro del apartado de Adversarios Sobrenaturales, del 400 al 459, dentro de los Encantamientos, y del 500 al 559, de Ayudantes Sobrenaturales, cuando en puridad deberíamos hablar simplemente de seres mitológicos de valencia múltiple, los cuales reúnen rasgos marcados (buenos o malos) o no marcados (amoral, ambivalente o ambiguo, tal como ocurre en la figura del Trickster). La bondad o la dureza (motivo Q2), la niña o novia buena y la mala, son en realidad marcas enfáticas que señalizan al (anti)héroe, que es quien sabe hacer un buen uso de los regalos o de los medios que están a su alcance.

La "niña buena" hace actos "felices" (Searle 1986), apropiados, y las recompensas refuerzan su naturaleza, y la "niña mala" hace actos inadecuados. El problema se hace más ostensible en el caso de los (des)encantamientos, donde no es fácil atribuir ni una fechoría como origen del mal, ni una prosopografía coherente que no esconda una forma subrepticia, un disfraz de algo que no se es, como en El Rey Rana. Solo de forma eventual cabría decir que Frau Holle es una entidad "buena" o "mala", esto es, benévola o malévola, porque eso dependerá de la forma de los encuentros con las personas, y cualquier predeterminación sería desconocer esta ambivalencia propia, por ejemplo, de los dioses o de los embaucadores (trickster), que lo mismo estafan o perjudican a los incautos con quienes tratan, que dan dones culturales a la comunidad, o que ellos mismos son engañados. Así, pretender clasificar los más de quinientos tipos de cuentos de magia con estas categorías, ahormados a su "intención" perversa o no, o bien por su aspecto (en lugar de por su funcionalidad u objetivos, o sea, para qué hacen lo que hacen), genera bastantes inconsecuencias.

Todo ello justificó el revolucionario replanteo que hizo Propp (1928) en Morfología del Cuento: buscar funciones y actantes, en lugar de motivos libres y personajes que fueran simples avatares del papel que desempeñan. Los análisis semióticos y antropológicos (por ejemplo, las teorías de Lotman 1979, o de Graves 1948) vienen a demostrar que los mitos se vuelven opacos a medida que sus códigos se oscurecen, o bien que las nuevas culturas reinterpretan sus textos con claves distintas, esto es, en sentido diferente o incluso contrapuesto. Así, las historias de la ondina (Nixe) de los cuentos de los hermanos Grimm, del duende (Rúmpeles Tijeles) o de Frau Holle fabulan sobre el posible sacrificio de un niño, si bien la secuencia inicial es reinterpretada en forma dispar. Unas veces la ondina se comporta como una 
bruja que ha secuestrado a los niños; otras, como en Frau Holle, es ella la que les propone pruebas en un contexto mucho más ambiguo, de modo que un texto puede presentar de una misma figura mitológica una imagen más amable y otra más siniestra.

Lo hemos señalado anteriormente: lo que subyace es una hermenéutica contractual, o sea, una especie de pacto entre donante y oferente, cuyo bien en juego es la curación o el saber oracular, es decir, lo que mágicamente podían proporcionar en tanto que divinidades tópicas, vinculadas a los poderes de la tierra y del agua. La relectura desde la ecocrítica hace, pues, repensar las categorías: los depredadores no son tales, sino acaso númenes tutelares; los matrimonios entre seres mitológicos y personas (el ciclo animal-novio, Bettelheim 1977) se vehiculan a través de los episodios de (des)encantamientos, y forman parte de esta misma lógica contractual: ambos mundos intercambian cosas y están sujetos a tabúes o prohibiciones. Los códigos del chamanismo explicarían con facilidad esta identificación o desdoblamiento del alma con su réplica animal o espíritu guardián (en los cuentos tiende a ser un monstruo grotesco), que se corresponde exactamente con el episodio de Calipso y Odiseo, quien permanece en la cueva en una suerte de trance extático. Son, pues, enclaves iniciáticos y, a la luz de esta iniciación, debe entenderse la polivalencia de los símbolos. El mismo Propp, a pesar de su narratología estructuralista, dejó claro que el esquema funcional que trazó en Morfología del Cuento solo cobraba sentido gracias a las claves histórico-antropológicas, explicadas en la reconstrucción que supuso su obra Raíces Históricas del Cuento.

Así, por citar un caso, las leyendas de desapariciones o de raptos han sido muy frecuentes dentro del folktale (Aarne-Thompson 1961) en todas sus modalidades: en los mitos, donde vemos que Zeus u otros dioses raptan mortales para sus fines amorosos u otros motivos, y en las leyendas y en los cuentos, donde el rapto o secuestro es un leitmotiv. De hecho, en los Cuentos de Adversarios Sobrenaturales de Aarne-Thompson (Tipos 300-479 del Catálogo de Aarne-Thompson, 1961) lo que más hacen el dragón, el ogro, el gigante, el genio, el diablo, el vampiro, etc., es acechar y apoderarse de su víctima, bajo distintas formas. Pero esto no prejuzga que "sea para mal", ni siquiera el devoramiento es una forma de depredación sin más, sino un ritual iniciático, según se ve en relatos como el de Santa Margarita, tragada por el dragón y que sale del vientre del mismo. Es un motivo recurrente en muchos héroes de los cuentos, que se arrojan a la boca de un pozo, en una clara equivalencia al hecho de ser tragados por un monstruo iniciático. 
Con todo, el principal escollo es siempre la comprensión del mito, en la doble dimensión que estableciera W. Mignolo (1978), la comprensión hermenéutica y la comprensión teórica. Esta última supone que el receptor no solamente interpreta la literalidad del texto, sino que es capaz de proyectar en él un modelo explicativo, que, en este caso, es como verificar si existe una gramática universal de la narración. Dicho de otra forma, V. Propp (1928) ya propuso dos niveles de análisis: poner de relieve la estructura secuencial del relato y ocuparse del problema de su génesis; ambas resultan investigaciones complementarias, pues la primera llevó a determinar una morfología del cuento maravilloso, y la segunda vinculó la estructura de éste a los pasos y transformaciones del rito de iniciación. Esta exégesis permitía toda una apertura hermenéutica, pues consideraba el cuento como una unidad de fábula en sí misma, con sus propias leyes de composición, pero a la vez subrayaba el papel modelador que tienen las experiencias histórico-sociales.

El problema, a la hora de analizar las leyendas tradiciones y su prolongación en la cultura mediática y digital, es que su estructura difiere en el fondo y en la forma de la del cuento maravilloso, de forma que las conclusiones que se obtienen cuando hablamos de Piel de asno o de Caperucita no son trasvasables sin más a este género. Y es que la leyenda no es un género ficcional como lo es el cuento, no pretende agradar o entretener a partir de una historia interesante; lo específico de la leyenda es ser memoria construida con imágenes poéticas, si hemos de aceptar la sugerente formulación de H. Gunkel (1910). Por tanto, es un discurso que practica el lenguaje de la vinculación -de asociación a hechos, lugares, personajes supuestamente verdaderos-, y esta reivindicación de su veracidad es lo que también explica, en parte al menos, su naturaleza fragmentaria, pues a veces todo lo que tenemos es un texto muy breve, una alusión, una canción o un topónimo, y, a la vez, elástica, dado que unos hechos se pueden enhebrar con otros hasta formar gestas y ciclos épicos. Por último, la leyenda es también "porosa", pues no en vano muchas historias verbales se transcodifican en cuadros, exvotos, rituales y otros géneros discursivos.

En conclusión, hay un mismo discurso mítico, pero no es igual según el "molde" elegido, ya sea el mito, la leyenda o el cuento, que imponen sus convenciones y sus perspectivas. En todo caso, comparten una lógica interna, un armazón, que los estudiosos de los mitos o los cuentos han puesto de manifiesto, y que son los patrones o tipos narrativos, cuya universalidad es un hecho fuera de toda duda. Así, en prácticamente todas las culturas se observan seres equiparables a los ángeles, demonios o genios, lo mismo que 
se suceden historias de encuentros con estos númenes, que unas veces son funestos y otras beneficiosos.

Antropológicamente, ya M. Eliade (1963) estableció que lo que ocurría dentro de un mito solía tener un carácter arquetípico, ejemplar, fundamento por tanto de los rituales y creencias de una comunidad. Y lo mismo pasa, a nivel más reducido, con las leyendas ancestrales que señalan en un pueblo los megalitos o lugares de encantamientos, y otros prodigios dignos de ser conservados en la memoria de la comunidad. En ese contexto concreto, el mito es dogmático porque cuenta algo etiológico del mundo (cosmogonía) o de la comunidad, a través de las leyendas de los héroes locales o de otros mitos fundacionales. Por tanto, la disfunción principal respecto al modelo de la escuela histórico-geográfica ha sido pretender ahormar con unas herramientas muy racionales y "desmenuzadas" lo que era, de entrada, un fenómeno lleno de complejidad y de contradicciones (coincidentia oppositorum), y hacerlo además con categorías formales y temáticas más que discutibles. Esto no obsta para que, sin embargo, se hayan afianzado tales taxonomías, creando descripciones que ponen el énfasis a veces en lo banal o anecdótico.

Tal vez el eurocentrismo y el racionalismo hayan pretendido fosilizar o ahormar en exceso lo que sin duda es, como dice Castoriadis (1999), un "magma creativo", y tampoco hayan tenido en cuenta la dimensión dialógica de la tradición. Es decir, en el supuesto de que hubiera un prototipo canónico de las historias de Frau Holle, nada nos permitiría excluir que la recepción de las mismas por lectores futuros llegase incluso a cambiar el sentido o la interpretación hoy predominantes de dicha historia. Si aplicamos las categorías de estudio de la historia de la mirada, vemos que ese desfase ya se ha producido: así, la tosquedad, el aspecto monstruoso o grotesco, los ruidos aparatosos, las risas u otros medios apotropaicos tenían pleno valor en el cuadro de la cosmovisión mágica, donde estas ondinas eran vistas como ídolos o representaciones sagradas a venerar, temer o impetrar, pero no ya en el marco actual de conductas, de ahí que no se entienda, como venimos subrayando, que la niña se pinche y vierta su sangre al pozo. Siguiendo con la historia de la mirada, con el Renacimiento se impondrá una mirada estética, lo cual encaja con el devenir de este cuento, convertido por los hermanos Grimm en una especie de juguete o deleite estético, al igual que las ninfas presentadas por Garcilaso o Botticelli en sus obras.

Donde quedan retazos claros de esta función sagrada o de "espanto" de las narrativas míticas es en el folclore infantil de las nanas, cuyas canciones para "asustar" han conferido una finalidad pragmática a estas historias. Uso 
que ya conocemos desde el gorgoneion, la máscara de Medusa utilizada para apartar a los niños de la puerta de un horno o de la boca de un pozo. Normalmente, la lectura "sensata" de tales historias apenas prestaba atención a los detalles, porque, al igual que hizo Perrault con los cuentos populares o el padre Feijóo con las supersticiones, se pensaba que, en el fondo, eran historias disparatadas que debían mucho al "capricho" de la imaginación.

Hoy no solo la ciencia, la antropología simbólica, la hermenéutica o la ecocrítica, el propio público se ha acostumbrado a procesar estas historias "en clave", a buscar las conexiones con el entorno inmediato o la realidad histórica cercana. La industria del entretenimiento, especialmente tras el boom de El Señor de los Anillos, ha favorecido la empatía del lector o del espectador haciendo que se plantearan nuevos niveles de interpretación, y cada historia nueva o cada saga haya supuesto retos novedosos de desciframiento, a través de juegos cada vez más complicados (Alien vs. Predator). Este mismo emparejamiento entre el terror de la saga de origen y sus extrapolaciones metafísicas actuales -el filme Prometheus fabula sobre el origen de la humanidad- revela bien hasta qué punto ahora es el lector quien descubre nuevas conexiones para integrar textos, discursos o géneros.

\section{ESTUDIO DE CASOS: MÁSCARAS, ESPANTOS Y SEDUCCIONES. LA ESCENOGRAFÍA DE LAS HIEROFANÍAS COMO (DES) APARICIONES}

Estos tres motivos mencionados están relacionados más de lo que pudiera parecer, desde el punto de vista de las narrativas míticas, pues se trata en los tres casos de producir un impacto emocional sobre la víctima, para apoderarse de ella. Constituye, pues, una estrategia depredadora, como bien vemos en la bruja de Blancanieves, la cual combina el aspecto metamórfico y la seducción del objeto ofrecido. Todo ello obedece a una cuidada puesta en escena de la "aparición" del numen o ser maravilloso, ya sea un hada, un vampiro o un alien. En Teología y en Historia de las religiones hay siempre una continua polémica sobre los modos de manifestación de la divinidad. Quizás sea R. Otto (1980) quien ofrece una imagen más completa de la hermenéutica de la divinidad, al describir los grados y matices de la experiencia numinosa. En ello concuerda con la teología negativa o apofática, en el sentido de entender la divinidad como algo inconmensurable o inasible por el entendimiento humano. Solamente es posible entender lo que Dios no es, y eso abre el 
camino a una deconstrucción de las preconcepciones sobre Dios, de los estereotipos más comunes. Esta oscuridad o misterio connatural a la esencia de Dios, así entendida, solo puede ser iluminada de forma parcial por las experiencias que Otto llama el mysterium tremendum, y que se expresa en categorías tales como majestuoso, fascinante, sobrecogedor o pavoroso, las cuales tienen su correlato en las reacciones paralelas del sujeto humano a este misterio: anonadamiento, desconcierto, aniquilamiento...

Lo cierto es que las epifanías en el folclore -a saber, las apariciones de seres mitológicos en diversos contextos en cuentos, mitos o leyendascomparten unos grados muy similares. Por ejemplo, los espantos y asustaniños tienen una representación equivalente a estas manifestaciones del terror de la deidad, en tanto que manifestación sobrecogedora de la divinidad (deima panikon), que inspira las reacciones irracionales y de amedrentamiento. Es lo que subyace a las leyendas de Pan o a la reacción de Jacob ante Bethel, "lugar de Dios", y por eso mismo, lugar terrible. De hecho, inducir este temor hasta llegar al pánico, que paraliza y aturde, parece ser la intención del raptor. La máscara, el disfraz o el aspecto terrorífico de éste sirven para canalizar ese miedo que se quiere inducir, por eso no son un simple motivo más en el imaginario popular. Así, un resorte esencial en el cuento de hadas es la apariencia engañosa, fundamental para el agresor, pues el donante y el propio héroe (v. gr., Ulises en su combate con los pretendientes) se valdrán de ella en algunas fases de las peripecias.

El agresor, como la bruja de Blancanieves, se presenta por tanto en aspecto y actitud taimados, lo mismo que es engañoso el aspecto de las hadas y de otros donantes en los cuentos maravillosos. Todos estos casos forman parte de lo que Greimas (1970) llamaba "modo deceptivo", que dentro del álgebra de las funciones narrativas viene a significar "A no es A, en realidad es B". Como los personajes en el folclore carecen de la profundidad psicológica de los relatos literarios (o sea, la mudanza de carácter no se debe nunca a que el personaje haya evolucionado convirtiéndose de "bueno" en "malo"), entonces esta naturaleza engañosa del personaje solo cabe atribuirla a una percepción errónea de su oponente, y por eso es necesaria la dramatización. El mal debe parecer que es el bien, debe enmascararse en otra cosa.

Es por eso que los personajes que engañan, que se enmascaran, siempre muestran ingenio en "construir un aspecto", es decir, "orquestan" una escenografía, una actuación. Por ejemplo, en el cuento del Dragón el impostor se presenta ante el rey para "representar el papel" del auténtico héroe. La vista juega en todo ello un papel esencial: los juegos de lo visible agrandan y 
hacen magnífico un personaje que luego no es tal, como ocurre en El Mago de $\mathrm{Oz}$, y también el sonido es importante. De ahí que en tantas leyendas (cf. el hallazgo de la tumba del Apóstol Santiago en Galicia) sean tan importantes las luces y cánticos sobrenaturales que se perciben, y los resplandores o estruendos de todo tipo ("ruidos de Pan") son comunes en las leyendas de las casas encantadas, en cuentos como Los Músicos de Bremen. Y es conocido el aserto teológico de que el diablo siempre "hace mucho ruido".

La máscara, pues, es un recurso expresionista, en el sentido de que pone el énfasis en un rasgo caracterizado muy marcado. "Bondad"/“dureza" son dos ejemplos claros de la conducta de los héroes/heroínas, como apreciamos en Frau Holle y en otros cuentos. Pero un falso héroe o un agresor pueden atribuirse "bondad" o "valentía" como parte de una estrategia de simulación o de suplantación. Entonces, según las pautas del cuento, a este enunciado de "A es B", o sea el engaño, le sucede lo que el propio Propp llama "complicidad", es decir, el héroe -la víctima- se deja engañar y colabora con el agresor.

Quizás está mal usada la noción de "complicidad", porque el héroe/ heroína afectados en absoluto pretenden esa colaboración que es, desde luego, involuntaria. En la práctica, el resultado es idéntico: el héroe, por su ignorancia, se hace cómplice de su desgracia, lo cual revela la capacidad de seducción o manipulación por parte del agresor para envolver a la víctima, y eso es algo también muy común en leyendas de ondinas o Xanas y de raptos. Por tanto, la depredación no se presenta a menudo como un engullimiento o una agresión física, sino como una "captación mental y emocional" que anula a la víctima. La máscara juega un papel importante en todo ello, no olvidemos la encarnación de lo sagrado tal como ocurre en el teatro oriental de máscaras. De hecho, parece que el término "máscaras" remite a una voz latina que significa "fantasma".

Los festivales del folclore con procesión de máscaras (por ejemplo, San Sebastián y las Carantoñas) son siempre representaciones de espíritus que "visitan" la aldea. En esta identidad sagrada de la máscara, en lo que es vela y des-vela, consisten estos juegos de lo visible y lo invisible, propios de las apariciones: se muestra, se sugiere, se induce, y en ello la víctima tiene un papel activo, al terminar de construir, mediante pareidolias u otros mecanismos, el perfil del "otro", que se alimenta de su miedo, de su pánico. Lo cierto es que, siguiendo las teorías antes citadas, tal vez la faz más profunda de Dios sea inasible, de modo que todos los intentos de visionar o dar forma a estos seres de otra dimensión parecen tener mucho que ver con las filias y fobias del perceptor, y ello explica las formas humanoides y la reiteración de los 
mismos arquetipos en diferentes culturas. Y es que el aspecto monstruoso y grotesco que revela la máscara es la manera expresionista de dar forma a la alteridad. Así pues, el conflicto de la máscara o prosopon ("personaje") está entre el ser y el parecer. El mito de Medusa es un ejemplo perfecto de estas polivalencias. Si el final es el principio, es decir, si lo más auténtico es la cabeza decapitada, la máscara mágica de poder, desprovista de todo lo accidental -el resto del cuerpo-, entonces sus atributos o prosopografía son "figuraciones oblicuas", formas de acercarse al núcleo de su diversidad: el pelo como serpiente, la lengua fuera, los ojos centelleantes son así formas "grotescas" de representación pavorosa de la diosa madre, que reproduce en quien la mira lo que tiene en su interior: vergüenza, miedo, sumisión...

\section{NARRATOLOGÍAS E IMAGINARIOS POSMODERNOS}

En medio de un contexto teórico-práctico, donde han aflorado conceptos como transmedia o transliteratura, han surgido diversos imaginarios de la posmodernidad, donde temáticas como los robots o los aliens parecen configurar una "nueva" imaginería. Tras décadas de un verborreico desarrollo de historias y testimonios sobre objetos volantes no identificados, un etnólogo como Bertrand Méheust (1985) ha puesto el dedo en la llaga cuando sugirió que el fenómeno ovni no era otra cosa que la actualización de los mitos y el folclore primitivos, adaptados a la mentalidad de nuestro siglo. De esta forma, las abducciones extraterrestres serían la versión occidentalizada y contemporánea del tema del rapto por seres sobrenaturales. Para lo que él llama un "banco primordial de imágenes", el imaginario popular estaría apoyándose en lo que la primera ciencia ficción (la anterior a los años 40) ya diseñara. Haciendo una relectura no esotérica de la hipótesis junguiana, Méheust considera el mito ovni como una mutación de lo fantástico tradicional (folclórico), que ha encontrado un nuevo código en la imaginería tecnológica y científica. O sea, estaríamos ante lo que V. García de Diego (1958) llama transpersonificación, a propósito de las leyendas ligadas a los menhires o cuevas, donde un ogro es sustituido por un moro o un gentil.

Ocurre que muchos de los cuentos sobre los secuestros de gente por duendes o hadas muestran también varios de los mismos pasos y, a su vez, tienen grandes semejanzas con el modelo mitográfico de Campbell (1949). Todo ello viene a confirmar la misma simetría entre estas historias modernas y las antiguas consejas aplicadas a los demonios, hadas u otros seres que 
irrumpían provocando una experiencia que, con otra terminología, es idéntica. Por ejemplo, el olvido mágico.

Desde esta óptica, los ayudantes y adversarios encarnan por igual las formas de las distintas representaciones numénicas, buenas y malas, del Otro, según aparecen en el folclore: igual que en El Mago de Oz se desencadenan las representaciones de la bruja malvada, del hada, del león cobarde, del hombre de hojalata, del espantapájaros y del propio mago de $\mathrm{Oz}$, en los mitos clásicos ocurriría otro tanto: solo hay que considerar la lucha de Hércules y la Hidra, donde el héroe descomunal, con amigos y objetos mágicos, se enfrenta igualmente a un agresor-múltiple, la Hidra. Los paralelismos del "escenario de abducción" con visiones extáticas son algo común a todos los tiempos (ya aludíamos antes al episodio de Odiseo y Calipso). En cuanto a otras visiones que se cuentan en las abducciones, como la manipulación quirúrgica, forma parte de lo que en los mitos se describe como una prueba transfiguradora, por la cual el iniciando sufría manipulaciones por parte del brujo o mago.

En realidad, los seres raptores, por así llamarlos, participan de muchos rasgos de los que, usualmente, se conocen como ángeles, demonios, genios, hadas y otras clases de entes mitológicos. El catalogarlos como aliados o como adversarios sobrenaturales, tal como hacen Aarne-Thompson (1971), únicamente puede entenderse desde una hermenéutica restrictiva, en relación con lo que le parece al héroe desde su particular estado de perplejidad y confusión. De hecho, las escuelas de magia, que tanto abundan en la Edad Media y siempre capitaneadas por el diablo, subrayan el papel de éste como maestro iniciático, es decir, como dador de conocimientos y dones, que, en definitiva, es lo mismo que hace Frau Holle. Ésta es un personaje percibido lo mismo como aliada que como adversaria, de hecho actúa con esta doble valencia para cada una de las niñas que se someten a prueba, y no olvidemos que incorpora además rasgos siniestros (dientes monstruosos), que las versiones para los niños tratan de edulcorar, según vemos en el cuento de los hermanos Grimm, donde apenas es una alusión.

Por otra parte, la dicotomía igualmente artificial entre leyendas religiosas (Tipos 300-749) y leyendas maravillosas (Tipos 750-849) no deja ver otro tipo de protoleyendas muy arcaicas, que son las que se refieren a una cosmovisión no tan dualista del mundo, y por tanto de la moral, entre seres de luz y seres de tinieblas.

En pocas palabras, la mejor aproximación a estos fenómenos es, a nuestro juicio, la forma en que aborda esta cuestión Otto (1980), con su sentimiento de lo numinoso que sobrecoge, y que permite relativizar otros temas menores, 
como es, al fin y al cabo, la fisonomía cambiante de la divinidad, los seres mitológicos de mil caras. Es lo mismo que podemos apreciar en las figuras de las damas de agua, aparentemente afables, pero que como mujeres encantadas esconden una faz siniestra, o pueden incluso manifestarse como animales legendarios. Lo pertinente es que se comporten como predadores o devoradores de sus víctimas, que actúen infligiendo sufrimiento y crueldad (Freisedo 1985). Sea cual sea su intencionalidad, lo que cuenta es que estas (des)apariciones se revelen como parte de un escenario y una dramaturgia religiosa, capaz de anonadar al receptor, de modo que simulen taumaturgias, prodigios, apariciones súbitas, ataques u otras formas diversas. Los encuentros con estos entes terroríficos siguen unas pautas, no son aleatorios, igual que no lo es la forma de conducirse con Frau Holle, pues lo único que sabemos a ciencia cierta es que ocurren unos efectos determinados, a tenor del comportamiento que manifieste el héroe.

Lo que sí está claro es que el principio lógico de tercero excluido no es muy pertinente para estas historias: una deidad puede ser buena y mala, un héroe valiente y cobarde, una ninfa bella y monstruosa, y toda esa naturaleza proteica del numen asoma en figuras como el trickster -el embaucador o burlón- y se contradice, claro, con las versiones infantiles o con la lógica occidental y también judeocristiana, donde el binarismo debe organizar todo el material. Pero, en la terrible historia bíblica de Jefté y su hija (Jueces, 7:10:6, - 7:12:7), Jehová no se comporta de manera distinta al genio que exige el pago por la promesa imprudente en la historia de La ondina y el estanque.

Además, como venimos reiterando, la morfología tampoco es una pista del todo fiable: ocurre con las consejas modernas -si podemos llamar así a las leyendas urbanas- de aliens que no tienen pies (flotan), y que son equiparables a ciertas hadas que poseen pies de animal, como Melusina, o garras, como las lamias. Más certero nos parece el planteamiento de Jacques Vallée (1969): tal vez la taumaturgia se consiga mediante una escenografía construida precisamente para impactar o controlar mental y emocionalmente al receptor, hasta el punto de que la apariencia, el vestuario, el sonido o las luces conduzcan a un mismo fin, que para Vallée es el "engaño" a la humanidad, al igual que Freisedo habla de "falsos dioses". Al margen de tales reinterpretaciones neoevemeristas, que no es posible abordar aquí, se pone el énfasis en la orquestación teatral de tales experiencias, que actúan, intenciones aparte, como un desencadenante, como una "máquina de producir signos" de desconcierto, si se puede llamar así. 
Por ejemplo, bajar a una sima es siempre lo que los estudiosos llaman el "descenso a los infiernos". No somos topos ni murciélagos, de modo que meternos en una gruta es como volar, bucear en las profundidades, surcar espacios como el desierto o la Antártida, es decir, andar siempre en los límites de nuestras capacidades y, por eso mismo, desatar las llamados estados alterados de conciencia, o sea, los trances que los místicos y los chamanes solían practicar a menudo con técnicas de éxtasis bien conocidas. De modo que, ya sea en una leyenda asturiana sobre la guaxa que vive en la cueva, o bien en el conocido pasaje cervantino de La Cueva de Montesinos, lo que se activan son una serie de imágenes primordiales a las que cada cultura otorga un armazón y una interpretación congruente con su propia cosmovisión. Por eso las cuevas, grutas y "antros" han sido paisajes míticos donde han morado los dioses y los "ogros" de todos los tiempos. Dios y Lucifer, Devas y Asuras, dioses del Olimpo y titanes, avatares o disfraces de una misma realidad, donde los seres humanos se encuentran como el joven que "está aprendiendo" en la novela de Mark Twain El forastero misterioso, o como se proclama en tantos mitos donde siempre hay un dios civilizador o filántropo, como el sumerio Enki o el referido Prometeo.

\section{ESTUDIO DE CASOS: LAS NARRATIVAS DE MARCA, EL NEOEVEMERISMO DE ALIENS Y EL FICCIONARIO DE TROPES}

Existen numerosas manifestaciones de imaginarios posmodernos, pero a los efectos de nuestro estudio vamos a señalar lo que consideramos tres hitos significativos. En cuanto al primer caso, las narrativas de marca se explican por la emergencia del universo de superhéroes dentro de la cultura popular contemporánea. En nuestra sociedad donde tanto peso ha ganado la novela negra como fuente de entretenimiento, aunque también de autodiagnóstico, tal vez los héroes de estos mitos ancestrales, ahora reciclados o reprocesados en la era digital, se nos aparezcan en la actualidad como detectives de lo sobrenatural, igual que Van Helsing o que Constantine (de Hellblazer), es decir, como investigadores psíquicos de lo paranormal que conocen bien los "trucos" y saben enfrentarse a los seres de las mitologías (lo vemos en producciones televisivas o cinematográficas como Sobrenatural, Expedientes $X$, Hombres de negro, etc.).

Los dioses han bajado así de sus Olimpos a la "arena" de las luchas, que ahora no se dirimen en un bosque recóndito donde una ninfa se aparece a un 
pastor, sino en grandes escenarios y conflictos universalizados, que vienen a recrear los mitos clásicos en una relectura moderna, según se aprecia en la literatura (serie de novelas Ilion) o en el cine (Furia de Titanes), videojuegos, etc. Todo ocurre, pues, en un nuevo contexto transmediático, que se corresponde además con las llamadas narrativas de marca. En realidad, es una forma de trivializar el misterio, porque la articulación de un mito se ha sustituido por una especie de "estampación de marca", por un uniforme o estereotipo que refleja un carisma heroico, recibido sin la concatenación que hay en los ritos de iniciación. A este respecto, Mutantes, X-Men, Robots, etc., son encarnaciones de estos nuevos héroes surgidos al amparo de la fetichización de la tecnología, que han reemplazado a los antiguos dioses.

Peninou (1971), en su célebre artículo sobre publicidad, ya establecía los tres requisitos de la marca comercial: le oui, le nom y le caractère, esto es, hay que darle un nombre propio singularizador, buscarle una adhesión o empatía inmediatas e identificarla con alguna atribución o cualidad. En esta misma línea, L. Cencillo (1970) advertía que el mito moderno presentaba otras características diferenciales, pues en lugar de constelarse en un símbolo o en una leyenda, como el mito arcaico, se encarnaba en personas, en grupos, en empresas. Esto es congruente con la cristalización de los mitos modernos en entramados concretos, como el universo Marvel y su nómina (aparentemente larga) de superhéroes y superheroínas que, en realidad, tanto deben a los mitos heroicos, leyendas de santos y otras muchas fuentes literarias. Una de sus características más posmodernas es su tendencia a la hibridación, reciclaje o agregación, como se hace evidente en La liga de los Vengadores, La Liga de los Hombres Extraordinarios, etc., todo lo cual ha generado remix pintorescos, hasta el punto de articular un equipo donde un dios (Thor) colabora con otros superhéroes no menos estrambóticos, y tiene enfrente a un "supervillano", Loki, que, como paradigma del trickster, estaría bien lejos de ser esta personificación caricaturesca del destructor. Corroboramos así un ejemplo extremo donde la agrupación no es de textos sin más, sino de figuras (crossover) para construir una unidad o supertexto, que sigue en apariencia el esquema que Propp describió como "cofradía del bosque" (compañeros maravillosos en busca de una aventura), pero que aquí, en realidad, apenas es un pastiche. Precisamente porque surgen como una narrativa de marca, que tiene que explotar unas franquicias de empresa, y que para ello pone en valor los tres elementos subrayados por Peninou (1971), descritos antes: aprovechar unos nombres, promover un culto o admiración hacia sus gestas y distribuir las cualidades, para armonizarlas en un "trabajo 
de equipo" al servicio de ideales superiores, normalmente identificados con la conservación acrítica del statu quo. En suma, algo parecido a lo que se ha llamado "kitsch dulce", jalonado a veces con elementos de "kitsch agrio", que tan bien saben manejar los guionistas de toda esta literatura mediática, y la ficción gótica de moda es buena prueba de ello.

Tal efervescencia por la mitología, leída en claves modernas, únicamente puede ser entendida como una especie de lectura midráshica que justificaría la actualización de los mitos, el re-sentido que se les otorga desde distintos ámbitos. Por ejemplo, hay un caso muy ilustrativo que coincide con esta misma línea de secularización de los mitos, desmintiendo de algún modo las interpretaciones convencionales y, a la vez, proporcionando otras nuevas significaciones, a la estela de éxitos como El código da Vinci. Se ha llegado al punto de proponer una relectura de la Historia, acuñada como la llamada "teoría de los antiguos astronautas". En efecto, dentro de la cultura de masas, según Ronald H. Fritze (2009), es lógico que productos como los documentales Ancient Aliens obtengan gran éxito, pues se trata de saciar los gustos de una cultura pop de memoria corta y apetito voraz. Y es que no solo estas teorías expuestas en documentales, sino otras numerosas producciones audiovisuales, imágenes, libros de ficción y de no ficción, animaciones -desde Star Gate a la última versión de Ridley Scott, Prometheus, que es la precuela de Alien-han invitado al público a releer los mitos de una manera más universalista y menos particularista (el escenario es ya la Tierra, no solamente los parajes locales).

Con todo ello tal vez se estén cumpliendo las recomendaciones visionarias de Sloterdijk (2000), en cuanto a asumir una convivencia difícil con la alteridad, ya se llamen animales, máquinas o extraterrestres, pero lo cierto es que en este clima posindustrial y milenarista, en medio de crisis recurrentes que afectan a la economía y el medio ambiente, lo que más vende es un nuevo "ficcionario" que ha convertido a los aliens y todo lo relacionado con el más allá, el ocultismo o la paraciencia, en el nuevo "granero" de la literatura de ficción. No es de extrañar que las teorías conspiracionistas pretendan aportar una nueva luz sobre las (des)apariciones, aun cuando ello implique, a menudo, tintes más siniestros. Rasgos en sintonía, por cierto, con la subcultura gótica $\mathrm{y}$, desde luego, con ciertas clase de periodismo y de programas televisivos abiertos especialmente al sensacionalismo. De tal modo que estas lecturas se realimentan unas de otras, creando una especie de corpus de lecturas adictivas, por así decir, que cumple el requisito de Peninou: la aceptación incondicional por los miembros de esa comunidad de seguidores. 
No hablamos siquiera de sectas, sino de un sector amplio de público que, dentro de la segmentación de audiencias que ha favorecido la revolución digital, se decanta por estos temas e, igual que la cultura fan que "devora" sagas, termina por "idolatrar" ciertas producciones. Y, además, son consumidores transtextuales o transmediáticos, pues consumen indistintamente libros, series de televisión, cine, videojuegos... que versen sobre esas mismas temáticas.

En esta misma línea, Tropes-TV (tvtropes.org) es una wiki sumamente original, porque se presenta como un ficcionario abierto a la escritura colaborativa y a la transliteratura que, en realidad, se comporta como una enciclopedia narratológica, pero con un enfoque posmoderno, pues los temas se redactan desde una perspectiva no academicista, sino mucho más lúdica y personal, irónica a veces, y ofrece un ejemplo vivo de las múltiples conexiones que subyacen al discurso literario y, en particular, a cada "pieza" posible, ya se hable de un personaje, motivo, universo de ficción, etc. De hecho, TV Tropes Wiki se inició por los fans, y lo interesante de su desarrollo actual es que se nos presenta como una red participativa y de convergencia de medios y lenguajes, tal como preconizaba Jenkins (2008), y en esa medida prefigura lo que podrá ser una comunidad futura de lectores, unida por las redes sociales y por compartir experiencias lectoras en no importa qué medio, lenguaje o texto, del pasado o del presente. Esta disolución de fronteras y los nuevos clusters o emparejamientos que surjan son también un referente para nuevos agrupamientos de textos. Por ejemplo, si elegimos el ítem "manzana de la discordia" (http://tvtropes.org/pmwiki/pmwiki.php/Main/AppleOfDiscord) obtenemos un conjunto de citas transtexuales, que nos remite no solamente a los textos del folclore, la mitología y la literatura, sino también a anime, manga, comics, cine, TV, teatro, videojuegos, web, etc.

\section{CONCLUSIÓN}

Así pues, vemos que las narrativas de marca (con sus crossovers de superhéroes), o fenómenos como la interpretación neoevemerista de los dioses como aliens disfrazados, o el surgimiento de bases de datos como es Tropes, con un tratamiento diferente de la información y un arsenal de escrituras colaborativas, condicionan la forma de percibir la literatura, incorporando otras culturas literarias distintas a la visión clásica. En concreto, es emergente la importancia de los mitos o del juego transliterario y transmediático que supone perseguir una ficción base, por así decir, en diferentes lenguajes y soportes, así como 
los nuevos marcos mediáticos y digitales, susceptibles de operar cambios profundos como el acercamiento de la literatura y la informática.

Y todo ello se realiza no solo a través de la poética hipertextual, sino también poniendo en la encrucijada los conceptos que han venido siendo pilares de la poética clásica, como es el caso del concepto de autor, diluido en el concepto de escritura alógrafa (Besson 2004) y en las prácticas alternativas que supone el fan fiction. Algo similar cabe decir sobre las fronteras entre géneros o, en definitiva, sobre la separación entre lector, autor y texto, ahora cada vez más entreverados, merced a la revolución de los soportes y las aplicaciones. De hecho, neologismos recientes como escrilector o prosumidor dan cuenta de esta nueva dimensión participativa o recíproca de la creación en la era digital.

Al hilo del surgimiento de estos nuevos paradigmas, y de otros como la ecocrítica, constatamos que en este paso del antropocentrismo al ecocentrismo, en realidad, los aliens vienen a ser como los antiguos dragones, y la encarnación de la alteridad amenazadora puede tener su reverso terrible también (por ejemplo, Mitos de Cthulhu). La disyuntiva hermenéutica es clara: el sentido alegórico o el sentido literalista y, a la par, la aceptación o rechazo de las nuevas hipótesis, lo cual da lugar a la coexistencia de paradigmas y cosmovisiones. A modo de ilustración, la reinterpretación en clave ufológica del folclore o de las historias mágicas tradicionales (y también las narraciones milagrosas cristianas) ha dado lugar, como hemos visto, a un neoevemerismo cuyo objetivo final es la deconstrucción de estos mitos (según la llamada teoría de los antiguos astronautas) o de otras interpretaciones que alumbren mitologías nuevas como las que subyacen a las diversas teorías conspiracionistas. Todo ello, sin duda, va a generar, como si se tratase de un choque de placas tectónicas, una serie de seísmos culturales y sociales, a medida que el mundo se "transnacionalice" y se relean mitos fundacionales de las diferentes culturas - como la Biblia en nuestro caso- en un sentido diferente e, incluso, alternativo.

Las teorías auspiciadas desde Internet sobre la inteligencia colectiva, es decir, la capacidad de repensar toda la cultura heredada, chocan con la tendencia a "dirigir" primero el entretenimiento y después la mentalidad general por parte de las grandes corporaciones, que han redescubierto en estos mitos y en estas narratologías "tuneadas" el granero de sus industrias. En este contexto, la reinterpretación de figuras como Pan o el diablo en clave de Trickster o de otras figuras descritas, en definitiva, el desarme de ciertos estereotipos cada vez más presentes, supone un giro copernicano, en medio de una cultura mosaico que requerirá cada vez más de lectores inteligentes 
o, como dice el Quijote, de lectores "discretos", que sean capaces de deconstruir sus propias lecturas, igual que sucede con episodios como la Cueva de Montesinos, donde Cervantes sabe mezclar folclore, literatura y una fina ironía -afín a la de la posmodernidad-dirigida al "discreto lector".

En esta tarea, la educación literaria no es un aditamento más, ni la selección de textos puede limitarse a elaborar un elenco de textos/autores, sino que deben favorecer las conexiones críticas en el sentido que venimos argumentando. Un último ejemplo, Lorenzo Silva (2012) tiene una reelaboración del relato Ojos Verdes de Bécquer, que, a su vez, es una literaturización de numerosas historias de encantadas o mitos como Medusa (ya antes citamos el relato bíblico de la hija de Jefté como una historia simétrica de La ondina del estanque de los hermanos Grimm). El acceso a la literatura es llegar a la cadena de estas tradiciones e (inter)conexiones. Por lo tanto, habrá que arbitrar medios para que el necesario acercamiento a autores, géneros u obras significativas se repiense en procedimientos menos atomizadores, y en esto quizás la tematología sea un vehículo idóneo para esta consideración más abierta y comparativa, que permita, además, algo que los lectores modernos, al modo de Tropes, ya están habituados: los flujos de información desde un discurso a otro.

La lectura de antologías presupone una forma de leer fragmentos y de predisposición a la lectura extensiva, por contraposición a otras formas de lectura, como la intensiva. Con todo, la integración de textos no es únicamente una tarea del antologista o compilador. Según Oakeshott (2009), si la cultura es en su esencia escuchar las conversaciones en la que los seres humanos buscan eternamente comprenderse a sí mismos, entonces tienen sentido algunos fenómenos emergentes, como la necesidad de integrar o conectar ciertos textos o discursos. Hemos constatado que el modelo autor único-libro único se ha quebrado, en gran medida por el surgimiento de sagas, ciclos o narraciones en serie, que presentan estructuras abiertas y en los que puede cambiar el autor, el discurso o el formato, y donde es el lector el que completa o da sentido, a su manera, a la estructura inacabada o abierta que se le presenta.

En particular, el educador debe ser un experto en ofrecer lectura de textos integrados, o sea, un experto en Intertextualidad e Interdiscursividad, en Literatura Comparada, en artes en general, pues su propósito final es ayudar a buscar nexos significativos (un hilo conductor) entre todo ese material heterogéneo que se puede elegir. El hipertexto, por su multimodalidad, obliga a vincular el texto a imágenes, signos y, sobre todo, a un caudal inmenso de 
información con la que se relaciona. De hecho, Internet es "como un mar de citas".

En todo caso, la generación de estos itinerarios de lectura entre alumno/ profesor ha de respetar los principios del aprendizaje constructivista: según Ausubel (2000), el nivel más elevado de una red conceptual no es lo importante, porque se acomoda a los fines de la indagación propuesta, lo relevante es el flujo de información que vamos conceptualizando. Cabe subrayar la importancia de la lectura y la escritura como prácticas sociales y socializadoras (y eso compensa la tendencia al "autismo" del internauta), lo cual debe llevar a una compresión más amplia de la lectura y de su entorno, hasta el punto de que estos itinerarios ya no irían solo de un libro a otro, sino de un lenguaje a otro, o de un soporte a otro, ampliando, pues, el ámbito y el objeto de los estudios.

\section{BIBLIOGRAFÍA}

Aarne, Antti and Thompson, Stith. The Types of the folk-tale. A classification and bibliography. New York: Burt Franklin. Traducción de 1993, Hensilki: Academia Scientiarum Fennia, 1961.

Ausubel, David P.; Novak, Joseph D.; Hanesian, Helen. 1963. Psicología educativa. Un punto de vista cognoscitivo. 1963. México: Trillas, 2000.

Bajtin, Mijail. La cultura popular en la Edad Media y el Renacimiento. El contexto de François Rabelais. Barcelona: Barral Editores, 1974.

Bauman, Zigmunt. Modernidad líquida, Buenos Aires: Fondo de Cultura Económica, 2005.

Besson, Anne. D'Asimov à Tolkien, cycles et séries dans la littérature de genre. París: CNRS Editions, 2004.

Bettelheim, Bruno. Psicoanálisis de los cuentos de hadas. Barcelona: Editorial Crítica, 1977.

Brémond, Claude. La lógica de los posibles narrativos, V.V.A.A. Introducción al análisis estructural del relato. Buenos Aires: Tiempo contemporáneo, 1974.

Brescia, Pablo y Romano, Evelia. El ojo en el caleidoscopio. México: UNAM, 2006.

Campbell, Joseph. El héroe de las mil caras. 1949. México: FCE, trad. de 1972.

Castoriadis, Cornelius. L'institution imaginaire de la société. Paris: Editions du Seuil, collection Points-Essais, 1999.

Cencillo, Luis. Mito. Semántica y realidad. Madrid: Biblioteca de Autores Cristianos, 1970.

Chartier, Roger. El orden de los libros: lectores, autores, bibliotecas en Europa entre los siglos XIV y XVIII. Barcelona: Gedisa, 1994.

Eliade Mircea. Mito y realidad. 1963. Barcelona: Kairós, 1999.

Freisedo, Salvador. ¡Defendámonos de los dioses! Madrid: Editorial Posada, 1985. 
Fritze, Ronald H. "Sobre los peligros y placeres de enfrentar Pseudohistory". Históricamente hablando 10 (5): 2-5 http://muse.jhu.edu/journals/hsp/summary/v010/10.5.fritze.html, 2009.

Gadamer, Hans-Georg. Verdad y Método I. Fundamentos de una hermenéutica filosófica. Salamanca: Sígueme. Trad. Ana Agud Aparicio y Rafael de Agapito, 1977.

García de Diego, Vicente. Antología de leyendas de la literatura universal. 2 vols. Barcelona: Labor, 1958.

Garland Mann, Susan. The Short Story Cycle: A Genre Companion and Reference Guide. New York/London: Greenwood Press, 1989.

Graves, Richard. La Diosa Blanca. 1948. Madrid: Alianza Editorial, 1983.

Greimas, Algirdas Julius. En torno al sentido. Ensayos semióticos. Madrid: Fragua, 1970.

Gunkel, Hermann. Die Sagen der Genesis. 1910 (edición alemana de Ed. Mercer, 1997).

Ingram, Forrest L. Representative short story cycles of the twentieth century: studies in a literary genre. La Haya y París: Mouton, 1971.

Iser, Wolfgang. El acto de leer. Madrid: Taurus, 1976.

Jenkins, Henry. Convergence culture: la cultura de la convergencia de los medios de comunicación. Barcelona: Paidós, 2008.

Lotman, Youri. Semiótica de la cultura. Madrid: Cátedra, 1979.

Martos García, Alberto Eloy. "Lectores y Fans”. ¿Por qué narrar? Cuentos contados y cuentos por contar. Coords. Mar Campos F. Figares, Gabriel Núñez Ruíz y Eloy Martos Núñez. Cuenca: Ediciones de la Universidad de Castilla La Mancha, 2010. 231-244.

"Sobre el concepto de apropiación de Chartier y las nuevas prácticas culturales de lectura (el fan fiction)". Álabe 4. Diciembre $2011 \mathrm{http}: / /$ www.ual.es/alabe

Martos Núñez, Eloy. "Libros como objetos y libros como flujos textuales: lo tangible y lo intangible en la lectura y el patrimonio”. ¿Por qué narrar? Cuentos contados y cuentos por contar. Coords. Mar Campos F. Figares, Gabriel Núñez Ruíz y Eloy Martos Núñez. Cuenca: Ediciones de la Universidad de Castilla La Mancha, 2010. 179-188.

Mendoza Fillola, Antonio. "El proceso lector. La interacción entre competencias y experiencias lectoras". La seducción de la lectura en edades tempranas (coord. Antonio Mendoza). Madrid: Ministerio de Educación, Cultura y Deporte, 2002.

Méheust, Bertrand. Platillos Voladores y Folclore, Paris: Mercurio de Francia, 1985.

Mignolo, Walter D. Elementos para una teoría del texto literario. Barcelona: Crítica, 1978.

Mora, Gabriela. En torno al cuento: De la teoría general y de su práctica en Hispanoamérica. Madrid: Porrúa Turanzas, 1985.

"Silendra, ciclo cuentístico". Revista Chilena de Literatura 36 (1990): 113-119

Otto, Rudolph. Lo santo. Lo racional y lo irracional en la idea de Dios. Madrid: Alianza Editorial, 1980.

Oakeshott, Michael. La voz del aprendizaje liberal. Buenos Aires/Madrid: Katz editores S.A., 2009.

Péninou, Gilles. "Le oui, le nom et le caractère. Les mythes de la publicité". Communications. 17 (1971): 67-81. 
Pollastri, Laura. "Desordenar la biblioteca: microrrelato y ciclo cuentístico". El ojo en el caleidoscopio. Brescia, P. y Evelia, R. México: UNAM, 2006. 79-113.

Propp, Vladimir. Morfología del cuento. 1928. Madrid: Editorial Fundamentos, 1974.

Saint-Gelais, Richard. "La fiction à travers l'intertexte: pour une théorie de la transfictionnalité", coloquio on line Fabula Frontières de la fiction, web Fabula, 1999-2000.

Segre, Cesare. Principios de análisis del texto literario. Barcelona: Crítica, 1985.

Savater, Fernando. Malos y malditos. Madrid: Alfaguara, 1997.

Searle, John R. Actos de habla. Madrid: Ediciones Cátedra, 1986.

Silva, Lorenzo. El hombre que destruía las ilusiones de los niños. Editorial: Taurus, 2012.

Sloterdijk, Peter. Normas para el parque humano. Madrid: Siruela, 2000.

Thompson, Stith. El cuento folklórico. Caracas: Universidad Central, 1972.

Motif-Index of Folk Literature. A Classification of Narrative Elements in Folktales, Ballads, Myths, Fables, Medieval Romances, Exempla, Fabliaux, Jest-books and Local Legends. 6 vols. Copenhague and Blomington: Indiana University Press, 1955-1958.

Vallée Jacques. Passport to Magonia: From Folklore to Flying Saucers. Chicago: Henry Regnery Co., 1969.

Warren, E. Roberts. The Tale of the Kind and the Unkind Girls. Aa-Th 480 and Related Tales. Fabula. Journal of Folktale Studies. Supplement-Serie. B: Untersuchungen Heft 1. Berlin: Walter de Gruyter and Co., 1958. 